\title{
The Rise of China-Indonesia Relationship: Soft Power, Resources, and Prospect in the Future
}

\author{
Juniar Laraswanda Umagapi \\ National Research University Higher School of Economics Moscow
}

\begin{abstract}
China is the emerging powers that many people believe that in the many years later they will be the most productive country with the fastest growing economic development in the world. As a consequence, China would be the main actor for global integrations as well as one of strategic partners for Indonesia. This research employs qualitative research method to understand which aspect influence the most towards Indonesia and China partnership. This paper will show the future partnership between China and Indonesia in economic and socio-cultural aspect.
\end{abstract}

Keywords: China, Indonesia, emerging powers, economic, integration, sociocultural

\begin{abstract}
Abstrak
China adalah emerging power dimana banyak orang percaya bahwa dalam beberapa tahun ke depan China akan menjadi negara yang paling produktif dan perekonomiannya tumbuh pesat di dunia. Alhasil, China akan menjadi pemain utama dalam integrase global serta salah satu mitra strategis bagi Indonesia. Tulisan ini menggunakan metode penelitian kualitatif untuk mengetahui aspek mana yang paling berpengaruh terhadap kemitraan antara Indonesia dan China. Tulisan ini memfokuskan pada prospek kemitraan Indonesia-China dalam bidang sosio-kultural.
\end{abstract}

Kata-kata kunci: China, Indonesia, emerging power, ekonomi, integrasi, sosiokultural 


\section{Introduction}

China as one of the powerful actors in global integration become a part of any cooperation. As a number one population in the world and the world's secondlargest economy consistently appears among the top five trade partners for ASEAN members. Some ASEAN countries depend heavily on China, especially as a source of imports like Indonesia (Salidjanova et al., 2015). For the greater cooperation between Indonesia and China it will become one of a large cooperation in the world as both are top 5 largest population in the world but achieving the international unity will be so difficult. Indonesia was the first Southeast Asian country that established official diplomatic relations with China in July 2015 (Hong, 2015). Indonesia and China recognized their bilateral cooperation in the early 1950 and then suspended its relations with China due to an abortive coup in October 1965 that why their relationship is unstable.

Nowadays China is in the elevated position for their political and economic development growth. Many countries want to cooperate with China and be a major main market in the Asia and even in the world as China provide the big market with big consumer inside. As the largest population in the world, it will be easy to get a big customer in China. If we are looking carefully, almost all the market in every country had China product with the cheap price.

Recently, even Indonesia's prosperity has been increasingly tied to China's growth as their relationships are getting closer. China economic growth always increasing, and we can see that China product in every market in Indonesia however for their fair relationship Indonesia product also must be dominant in China market. China is Indonesia top 3 import partners and China position is always in the top three for the recent years. The top import origins of Indonesia are China $(\$ 32,1 \mathrm{~B})$, Singapore $(\$ 25,8 \mathrm{~B})$, Japan $(11,3 \mathrm{~B})$, Malaysia $(6,67 \mathrm{~B})$ and South Korea $(\$ 6,61 \mathrm{~B})$ (OEC Indonesia, 2016).

However, China is so conservative and still afraid to have many foreign relationships. For example, to open the NGO in China it is very difficult even with the positive mission. Only about 1 percent of the foreign NGOs believed to be operating in mainland China have registered as required by a new law, meaning that thousands could be operating in a risky legal limbo. As of this month, only 82 foreign NGOs had registered the representative offices in mainland China required by the new law, including a handful with offices in two or more provinces, according to the website of the Ministry of Public Security bureau tasked with their management. Foreign NGOs find it difficult to cooperate with China because they afraid that it will influence their national security if many institutions take control China economy social system (Gan, 2017).

Jakarta has become wary about the incompatibilities between the economies of the two countries, which drives the depiction of China as a strategic "challenge", rather than a direct "threat". These doubts constantly re-emerge whenever China is talked about in Indonesia. Indonesia had experience with anti-Chinese and anti- 
Communist sentiment over the history (Danubrata, 2017). Right now, the issue of communism become a hot issue again right now as they are afraid we will get influenced by the principle that we will have no rights, but China is not bad at all as they provide the good healthcare and education system so why we get offended by China communism.

On average, Indonesian Chinese are far wealthier than other ethnic groups especially for those who live in the small city. During riots leading to the fall of President Suharto in May 1998, ethnic Chinese were targeted, making up many of around 1,000 people who were killed in the violence. Under Suharto, Chinese culture and language were severely restricted, but at the same time, he cultivated some ethnic Chinese businessmen who became hugely rich (Danubrata, 2017).

Evan Laksmana (2016) in his research about the domestic politics of Indonesia approach to the tribunal ruling and the South China Sea clearly state that their relationship after the conflict of South China Sea occur that perceptions of China are more contradictory, this is what Indonesia think about Indonesia and China partnership after the South China Sea conflict. The poll by the Lowy Institute suggested that over half of Indonesians thought that China could "somewhat be trusted". However, nearly half of respondents in 2008 were worried that China could become a military threat. This is the survey after South China Sea conflict. This is what we need to see the different view regarding economic prosperity and their relation to social and cultural perspective. China policy towards South East Asia and ASEAN member countries make a powerful move for their economic partnership, South China Sea issue did not bring any big effect for their bilateral relationship. The issue if they can extend the impact for their bilateral relationship in Indonesia side more bring any interest discussion for the researcher. This is the hypothesis that the author wants to bring it in this paper.

China and Indonesia partnership will bring a lot of advantages for both countries, but many conflicts prevent their relationship and make their relationship becomes up and down. Natuna, South China Sea, communism issue is such a reason why their relationship become like this. That is why to understand how the economy and social- cultural aspect influence their relationship to be a better partnership. The research wants to prove about the impact of China and Indonesia relationship in the economy and social-cultural aspect, it is worth to continue their partnership or not and to prove that this is not an unfair partnership that only give an advantage to one party.

This research addresses several questions: How the prospect of Indonesia and China relationship in economy and social-cultural perspective? What is the problem to make this relationship be a great chance for both countries to develop their strength in several aspects like the economy and social-cultural aspects? Indonesia still has a lot of regional issues that they want to solve so what does the "China effect" mean to a low-wage country like Indonesia? 
Both countries still had a lot of challenges to make this partnership become a big cooperation and it is still not clear about the direct influence on the society in both countries in this cooperation. Indonesia experiences the dramatic retrogression at the time of Asian crisis in the late 1990s (Lindbland in Demmers, Jilberto \& Hogenboom, 2004) and it is so difficult to Indonesia in the time to gain their confidence about their foreign policy mechanism. Moreover, for China, they need to expand their product in all the market and Indonesia market consider as one of the big markets in the world. China tries not to influence their partner regional issues to make a more progressing cooperation in the future, but they always get involved in the global issues.

\section{China and Indonesia Economic Relationship}

I argue that Indonesia will see China as the most powerful country that can divide the power of the United States and can minimalize the need of Indonesia in the trade sector. Many actors believe that China nowadays become a world's second largest economy by nominal GDP after United States. Even it is still need a lot of time to prove that and become a world largest economy China still need a lot of effort and face a lot of issues and China need to solve a lot of their regional issues to be in top position. But we also cannot ignore China's progressing economy really going so fast and their product nominated mostly all the markets in developing countries and some of develop countries. Chine product are famous because of the quantity and their market price as they always restock the product and win the customer in middle economic group and below.

There are a few cases that make Indonesia and China relationship not going so well. For example, the tension between China and Indonesia after Navy Indonesia trying to detain a Chinese trawler accused of fishing in Indonesian area without permission and put their relationship in a tough situation. That's why we must consider building up the tight relationship again among them after this issue occur but without sacrifice the identity and characteristic of both countries.

In the economic bilateral perspective, it already shows a good improvement as in the recent year China always among top main countries of Indonesia's top import partners.

Table 1 Indonesia's Top Import Partners

\begin{tabular}{|l|l|l|l|}
\hline No & Countries & US\$ & $\%$ \\
\hline 1 & Japan & 18 billion & 12 \\
\hline 2 & United States & 16,3 billion & 10.8 \\
\hline 3 & China & 15 billion & 10 \\
\hline 4 & Singapore & 12.6 billion & 8.4 \\
\hline 5 & India & 11.7 billion & 7.8 \\
\hline 6 & South Korea & 7.6 billion & 5.1 \\
\hline 7 & Malaysia & 7.6 billion & 5.1 \\
\hline 8 & Thailand & 5.5 billion & 3.7 \\
\hline 9 & Taiwan & 5 billion & 3.4 \\
\hline 10 & Philippines & 3.9 billion & 2.6 \\
\hline \multicolumn{4}{|c|}{ Sources: World's Top Exports 2015} \\
\end{tabular}


Table 2 China's Top Import Partners

\begin{tabular}{|l|l|l|l|}
\hline No & Country & US\$ & $\%$ \\
\hline 1 & United States & 410.8 billion & 18 \\
\hline $\mathbf{2}$ & Hong Kong & 334.3 billion & 14.6 \\
\hline 3 & Japan & 135.9 billion & 6 \\
\hline 4 & South Korea & 101.5 billion & 4.4 \\
\hline $\mathbf{5}$ & Germany & 69.2 billion & 3 \\
\hline 6 & Vietnam & 66.4 billion & 2.9 \\
\hline 7 & United Kingdom & 59.7 billion & 2.6 \\
\hline 8 & Netherlands & 59.6 billion & 2.6 \\
\hline $\mathbf{9}$ & India & 58.3 billion & 2.6 \\
\hline $\mathbf{1 0}$ & Singapore Sources: World Top Exports 2015 & 2.3 \\
\hline \multicolumn{4}{|c|}{} \\
\hline
\end{tabular}

If we see the top import countries to Indonesia, China is the top three but it is different from China side as Indonesia did not include to the top 10 countries then it is mean that China product dominates in Indonesia, but it is not the same with Indonesia product in China. China will continue to take the market share in Indonesia. Chinese competition would be most fierce were textiles and garments, footwear and some electrical products will be their main commodity. Inroads of Chinese high-tech industry into the Indonesian market are symbolized by a wide assortment of electrical and electronic goods where China ranks among the top sellers. China telecommunication equipment dominate the market because of their cheap price and the quantity of the product. China always make a big supplier to enter the big market. For Indonesia mostly, their products are agricultural raw materials (rubber, wood, pulp, crude vegetable materials) as their mostly promote the agriculture sector that what China need the most from Indonesia. Oils, paper and paper board, chemical product mostly nominated also for China market (Lindblad, 2007).

China foreign policy for the past decade change significantly, the question whether China should focus primarily on their neighbour countries or the world major powers (the U.S) the question already clear that China now focusing for their neighbourhood diplomacy and they try to maintain the good relationship with South Korea, Japan, Russia and ASEAN member countries.

Indonesian exports to China grew more rapidly than total exports and accounted for around twelve percent of the total growth in dollar terms. Coal, palm oil, gas, crude petroleum, and crumb rubber are the most important products. Together these five products accounted for around 58 percent of total exports to China in value terms in 2009. Cumulative non-bond investment outflows from China to Indonesia in the years from 2005 to 2010 amounted to USD 9.8 billion, which made Indonesia the eight largest recipients of Chinese non-bond investment over these years, after Australia, the USA, Nigeria, Iran, Brazil, Kazakhstan, and Canada. It received more investment than any other ASEAN country, including 
Singapore (Booth, 2011). As China needs a lot of Indonesia natural resources and Indonesia also need the products that China produces.

This paper argues that Indonesia existence in China foreign policy priorities or vice versa will bring advantage for both parties. From China's perspective, since 2010 ASEAN has become its fourth-largest trading partner after the European Union, Japan, and the United States. Among ASEAN member countries, Indonesia was China's fourth-largest trading partner, which, according to data as of May 2010, from the Ministry of Commerce of the People's Republic of China, amounted to USD 12.4 billion, after Malaysia (USD 22.2 billion), Singapore (USD 17.9 billion) and Thailand (USD 15.7 billion (Chandra et al., 2011).

The Chinese market is important to the Indonesian export industry for one of two reasons. Firstly, a very large amount across the board, such as oil and gas. Secondly, China position as a leading buyer of commodities. Export values more than $\$ 100$ million are recorded for only eight commodities with China ranking among the top buyers. China is an important supplier of goods to Indonesia, both on account of large volumes across the board, as in textiles and clothing, and due to the strong market position in a whole range of branches. The considerable degree of diversification and increasing level of technological sophistication of Chinese products bear testimony to a highly successful performance in terms of competition both with other foreign suppliers and domestic producers (Lindblad, 2007).

China has further cemented its role as one of Indonesia's strategic partners going forward with the Asian commitment to continue this trend of investment. We just want to make sure that Indonesia later will be China strategic partner also because until now Indonesia position is still under the top 5 but we just have the hope because ASEAN still is China strategic partner, so I will be better in the future. Over the last thirty years, China's record has been the dead long pace of economic growth and it is really shocking dramatically change. Between 1978 and 2005, China's real GDP grew at an average annual rate of 9,5 percent. Before the end of that period, China had overtaken the United States as the world's largest recipient of foreign capital. By 2005 China was manufacturing 25 percent of the world's washing machines and 50 percent of the world's camera. The country had overtaken the United States in sales of television sets and mobiles phone and was expected shortly to become the world's largest market for computers. Alongside the domestic expansion of the economy, China has invested heavily overseas to secure sources of raw materials, most importantly Oil (Roberts, 2011: 310).

China and Indonesia trade partnership still can continue with a good impact in the future as expected if they maintain the import and export commodities. Indonesia can provide the commodities that China does not have it and vice versa. We just afraid that it is not only given a short-term comparative advantage in both academics that also a long-term advantage despite all the concerns regarding this partnership. This is a strategic option to embrace China, but it is better to manage their relations with other major power also. 


\section{Cultural and Tourism Sector}

It is easy to use soft power as a tool to gain more recognition from the other country, cultural exchange will be one of the best method to promote both countries more. If we want to promote the country better, it is easy to use tourism sector also because many people around the world like to travel and it will influence the economic sector also as a country will get a lot of income by the increasing of tourist every year.

For the cultural aspect, Indonesia and China are rather similar because as a large country both customs and traditions of its people vary by geography and ethnicity. With more than 1 billion people live in China representing 56 ethnic minority groups. The largest group is the Han Chinese, with about 900 million people. Other groups include the Tibetans, the Mongols, the Manchus, the Naxi, and the Hezhen, which is the smallest group, with fewer than 2,000 people (Zimmermann, 2015). It is quite a lot of different customs live in one country and this is also the point to promote China in international level. In Indonesia exist more than thousand ethnic group and many local languages existed as the history of Indonesia this local language still exist until now despite Bahasa Indonesia as a national language that more than 260 million people speak with that language.

In the cultural and tourism sector, a youth of Indonesia especially who study in China can promote the culture more, so we can exchange our culture is also one of the best ways to make them know better about each country and make them want to visit the country in the future. As we know that every year much Chinese tourism visits Indonesia and Chinese culture famous in Indonesia as the history many Chinese live in Indonesia also. Indonesia students abroad, especially in China, make a lot event that can promote Indonesia like Wonderful Indonesia and until now Indonesia students already make a lot of events to support Indonesia tourism. Education and tourism are the foundations of people-to-people relations, concluded speakers in the sixth Indonesia-China bilateral relations seminar conducted by the Centre for Strategic and International Studies (CSIS) and the Chinese People's Institute of Foreign Affairs (CPIFA) in Jakarta. People-to-people relations through student exchanges and tourism play a key role in clearing up misunderstandings regarding treatment of Chinese people in Indonesia or treatment of Muslims in China (Heriyanto, 2016).

Under Jokowi government, it looks like the government tries to strengthen their relationship with other country use tourism sector as a marketing system to boost up their economic progress. Jokowi wants to boost tourism industry to $7,5 \%$ of GDP by 2019, China is on track to become the biggest tourist market for Indonesia for the first time this year, overtaking Singapore. That's after a 46 percent surge in visitors from the world's second-largest economy to 1.4 million in the first eight months of the year (Salna, 2017). Indonesia know better than to boost the tourism sector it will strengthen their relationship also because the biggest group of tourists comes from China, so it will be important to make China to always comes 
to Indonesia every year and their number will be increasing also. To transform the tourism industry the government, promote the other city also so people know more the other city and it will be balanced as not only Bali is good for traveling. "All over the world they are trying to catch the Chinese market," Indonesia's Tourism Minister Arief Yahya said in an interview in Jakarta. "For sure, the easiest way to increase the number of tourists is to target China." While Indonesia currently captures about 1 percent of the more than 120 million Chinese who travel abroad each year, Yahya is aiming to double that, targeting advertising in key locations in China (Salna, 2017). Every country tries how to gain China people trust to travel in the country because Chinese tourist are famous to travel with a large group and it will easy to gain their trust collectively.

\section{Chart 1. Tourist arrivals by country of origin}

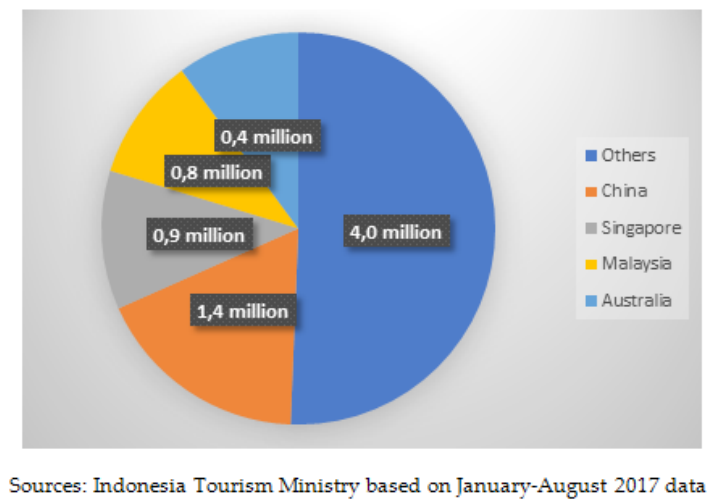

For China taken up as the world largest population in the world, China had a lot to offer. Economic progress, infrastructure developing, culture, sports, big market and so on. The domestic markets benefit a lot from the large population, that is also the reason that China also take it seriously to transform their tourism industry. The World Tourism Organization predicts that China will become the largest travel destination and the fourth largest source country by 2020. In that year, there will be 137.10 million international travellers to the country, taking up $8.6 \%$ of the global share (Travel China Guide, 2016).

Chinese literature also famous in Indonesia, many institutions open the Chinese language course and Chinese is the most famous foreign language after English and place second as the foreign language that most people in the world can speak (Nurridha, 2017). It is proven also with many Chinese language center open in Indonesia. Youth believe that as the number one biggest population in the world and look at the reality that Chinese almost everywhere in every region of a country around the world make them understood to study the language as the globalization era forcing right now. The need for Chinese language expert in Indonesia is very 
helpful for many institutions as the language also the national language for United Nations.

For the fast improvement, China proves to be the single country who move so fast for the economic development growth. China literature, culture and identity spread over the world. The term that "China's everywhere" is not only a term but the proof that the Chinese are in every position for a big company around the world. Every year China imports a lot of product to Indonesia and the Chinese product is so cheap compared with the local product that is why Indonesian product needs a lot of arrangement for the price even the quality is Indonesia the best.

The increasing number of tourist in both countries also because of two biggest airplanes in both countries Air China, China South Airlines, and Garuda Indonesian airlines opened direct flights between the two countries so it will be easy to fly over the countries. The Indonesia-China Association of Economic, Social and Cultural Cooperation was founded in July 1992, and the China-Indonesia Association of Economic and Cultural Cooperation was founded in August 1993. The two associations signed an MOU on cooperation. In addition, the two sides signed an MOU on the promotion of cooperation in tourism, and MOUs on health and sports cooperation. In July 2000, the two countries signed an agreement on mutually granting judicial assistance to each other. In September 2000, China approved Indonesia to be a destination for the outbound tour of Chinese citizens (China Embassy in Indonesia, 2011).

Cultural ties between both countries must be an open door for the other various fields as culture, science, and technology, education, health, military affairs, religion, tourism, communication, agriculture, and forestry. China as the powerful country will be a real challenge for Indonesia because the other perspective will think that China closer ties with Southeast Asia countries like Indonesia to make China get more access and power in the region and make them open the big market, especially in South East Asia.

Cooperation between local governments in both countries also makes a good impact. Beijing built up ties of friendship cities with Jakarta, the Indonesian capital city and letters of intent have been reached for establishing friendship relation at provincial level between East Java and Shanghai, Guangdong Province and North Sumatra, Fujian Province with Central Java and Hunan Province with West Nusa Tenggara. Last Beijing Olympics in China is not only about sports competition. They were intended to showcase "China's economic, technological, cultural, social and environmental achievements to the rest of the world. They set the agenda for how China would be understood both within the country and throughout the world.

In the future, China foreign policy will still as the US and EU main partnership, China also looking for the new power like Russia as China build many investments in Silk Road Economic Belt as a geopolitical project because it will help China to set a new trade route as an outlet in steel manufacturing and heavy equipment. China tries to be the middle actor and not involved in the Russia and 
US diplomatic issue regarding terrorism etc. As China also involved in Euro Asian Economic Union and they plan to create free trade agreement and China looks positively about that program. China also will focus on their neighbour country like Japan and South Korea as the history prove that this three-major's country such as China, Japan, and South Korea partnership is strong compared with other countries and the last ASEAN member countries as Singapore still be China strong candidate in the market sector and soon all members of ASEAN.

\section{Conclusion}

The exchange of culture also will be the focus and the tool for both countries to strengthen their cooperation. Indonesia student or the Indonesian embassy there must be active to create many events such as Festival Indonesia etc. To make Chinese people there has a knowledge about Indonesia. We can see that Indonesia is so famous as every year the tourist of China always spends their holiday in Indonesia, but we must make sure also that this is not only because Indonesia is very cheap country compare with the other country in Europe. That is why to promote Indonesia is still the focus and vice versa promote Chinese culture in Indonesia even it is actually very easy because Chinese culture is a part of Indonesia because of the history also.

Indonesia has become more comfortable and confident toward China. However, Indonesia still worries about China existence power in the region. Indonesia remains uncertain about China's long-term intentions in Southeast Asia. There is no guarantee that in the future a powerful China, both in economic and military terms, would continue to be a status quo power. Indonesia, like other ASEAN member states, would not want to see China seeking to dominate the region, nor defining its relations with ASEAN states in terms of competing with other major powers (Sukma, 2009).

Their relation becomes worse because of the tensions in Natuna sea but right now it is becoming better again. China will be the best actor for Indonesia to learn about the growing economic China had and how they managed their population growth. China has a lot to offer to Indonesia and Indonesia will see this as a chance for them to becoming a strategic partnership again.

On a personal level, observers have noted that Jokowi feels a strong and cordial rapport with Chinese President Xi Jinping and that they communicate regularly. But the role of cabinet members believed to be "pro-China" in their positions cannot be underestimated. These members, particularly State-Owned Enterprises Minister Rini Sumarno, and the then Coordinating Minister for Political, Legal, and Security Affairs Luhut Pandjaitan (who is now Coordinating Minister for Maritime Affairs), are among Jokowi's most trusted advisers, especially on foreign policy. They are Jokowi's top political operators and he relies on them to get most of his Indonesia's Approach to the Tribunal Ruling 387 policy agenda off the ground. In fact, arguably, Jokowi cannot win a re-election campaign without 
these two figures running the show. While Sumarno's ties with Beijing have been reported during her time as a minister under the Megawati administration (200104), Pandjaitan's business empire expanded after he joined the Jokowi bandwagon. Pandjaitan's role in shaping China policy is noteworthy, as officials occasionally noted how his staff would run interference during some of the ASEAN-China diplomatic meetings. With these key players essentially determining China policy at the top, other bureaucratic players - from the ministries of fisheries, defense, and foreign affairs, to the different maritime security agencies — had to argue among themselves, which further hindered the formulation of a coherent South China Sea policy (Laksmana, 2016: 382).

China history, ideology, law and economic system are all very different with another country, sometimes it is not unpredictable how China government lead their country even China position in international cooperation still make another country wonder how far China will intervene the global issues. China needs to work hard to win acceptance from the group of countries that have held sway since the Second World War.

\section{References}

Booth, A. (2011) China's Economic Relations with Indonesia: Threats and Opportunities. Journal of Current Southeast Asian Affairs 30(2), pp. 141160.

Chandra, A.C. \& Lontoh, L.A. (2011) Indonesia-China trade relations: The deepening of economic integration amid uncertainty? (online). Available at: <http://www20.iadb.org/intal/catalogo/PE/2012/09603.pdf> [accessed 10 October 2017]

China Tourism (2016) China national Tourism Administration (online). Available at: <https://www.travelchinaguide.com/tourism/> [accessed 10 October 2017]

Chinese Embassy in Indonesia (2011) China and Indonesia Ties (online). Available at: <http://www.china.org.cn/world/experience_china_in_ indonesia/2011-06/29/content_22885834.htm> [accessed 27 December 2017]

Danubrata, E. \& Suroyo, G. (2017) In Indonesia, labor friction and politics fan antiChinese sentiment (online). Available at: <http://www.reuters.com/article/ us-indonesia-election-china-idUSKBN17K0YG> [accessed 18 April 2017]

Gan, N. (2017) Why Foreign NGOS are struggling with new Chinese law (online). Available at: <http://www.scmp.com/news/china/policies-politics/ article/2097923/why-foreign-ngos-are-struggling-new-chinese-law> [accessed 27 December 2017]

Heriyanto, D. (2016) Indonesian-Chinese people-to-people relations: Growing but underdeveloped (online). Available at: <http://www.thejakartapost.com/ 
academia/2016/11/23/indonesian-chinese-people-to-people-relationsgrowing-but-underdeveloped.html $>$ [accessed 27 December 2017]

Hong, Z. (2015) China and ASEAN: Energy security, Cooperation and Competition. Singapore: ISEAS.

Kumparan,L.N.(2017) 12 foreignlanguagethatmostlypeopleusein theworld(online). Available at: <https://kumparan.com/luthfa-nurridha1487566251351/12bahasa-asing-yang-paling-banyak-digunakan-di-seluruh-dunia> [accessed 27 December 2017]

Laksmana, E. A. (2016) The domestic politics of Indonesia's approach to the tribunal ruling and the South China Sea. Contemporary Southeast Asia 38(3), pp. 382388.

Lindblad, J. T. (2007) Indonesia and China Today: New Challenges with a Long History. Journal of Developing Societies 23(3), pp. 369-392.

OEC Indonesia (2016) Export, Imports and Trade Partners (online). Available at: <https://atlas.media.mit.edu/en/profile/country/idn/> [accessed 27 December 2017]

Roberts, J.A.G. (2011) A History of China, 3rd edn. New York: Palgrave Macmillan. Salidjanova, N., Weser, I.K., \& Klanderman, J. (2015) China's Economic Ties with ASEAN: A Country-by-Country Analysis (online). Available at: <https:// www.uscc.gov/sites/default/files/Research/China $\% 27 \mathrm{~s} \% 20$ Economic $\% 20$ Ties\%20with\%20ASEAN.pdf> [accessed 27 December 2017]

Salna, K. (2017) Like Bali? Indonesia wants to create 10 of them to draw Chinese Tourist (online). Available at: <https://www.bloomberg.com/news/ articles/2017-10-19/creating-10-new-balis-indonesian-tourism-plan-startswith-china $>$ [accessed 27 December 2017]

Sukma, R. (2009) Indonesia-China Relations: The Politics of Re-engagement. Asian Survey, 49(4), 591-608.

World Top Exports (2015) Indonesia's Top Trading Partner (online). Available at: $<$ http://www.worldstopexports.com/indonesias-top-15-import-partners/> [accessed 27 December 2017]

Zimmermann, K. A. (2015) Chinese Culture: Customs and Traditions of China (online). Tersedia dalam: <https://www.livescience.com/28823-chineseculture.html $>$ [accessed 27 December 2017] 